SUPPLIER SELECTION CONSTRUCT: INSTRUMENT DEVELOPMENT AND VALIDATION

\author{
Chin-Chun Hsu * \\ University of Nevada Las Vegas \\ College of Business \\ 4505 Maryland Parkway, Box 456009 \\ Las Vegas, NV 89154-6009 \\ Tel/Fax: (702) 895-3842 / 4370 \\ vincent.hsu@unlv.edu \\ Vijay R. Kannan \\ Department of Business Administration \\ College of Business \\ Utah State University \\ Logan, UT 84322-3510 \\ Tel/Fax: (435) 797-7212/2634 \\ v.kannan@usu.edu \\ G. Keong Leong \\ University of Nevada Las Vegas \\ College of Business \\ 4505 Maryland Parkway, Box 456009 \\ Las Vegas, NV 89154-6009 \\ Tel/Fax: (702) 895-1762/4370 \\ keong.leong@unlv.edu \\ Keah-Choon Tan \\ University of Nevada Las Vegas \\ College of Business \\ 4505 Maryland Parkway, Box 456009 \\ Las Vegas, NV 89154-6009 \\ Tel/Fax: (702) 895-3873/4370 \\ kctan@unlv.nevada.edu
}

March 15, 2006

(Second Revision - International Journal of Logistics Management)

(* Authors are alphabetized, corresponding author.) 
Chin-Chun Hsu is Assistant Professor of International Management at the University of Nevada, Las Vegas. He received his Ph.D. in International Business from Saint Louis University. He has published numerous articles in the areas of international strategic management, cross-cultural management, marketing research, and social networks in a variety of journals, including Journal of International Business Studies, Management International Review, Journal of Business Research, Multinational Business Review, Journal of International Consumer Marketing, and Journal of American Academy of Business.

Vijay R. Kannan is Vernon Maughan Buehler \& Maree C. Buehler Endowed Professor and Professor of Operations Management in the College of Business, Utah State University. Dr. Kannan earned his BSc. from the University of London, MBA from Indiana University and Ph.D. in Operations Management from Michigan State University. He has published extensively in the areas of cellular manufacturing, quality management, and supply chain management, his articles appearing in journals including Decision Sciences, International Journal of Production Research, International Journal of Operations and Production Management, OMEGA, and Quality Management Journal. His current research examines the impact of buyer-supplier relationships in supply chains and the application of systems thinking to management education.

G. Keong Leong is Professor and Chair of the Management Department in the College of Business, University of Nevada Las Vegas. He holds a Bachelor of Mechanical Engineering from the University of Malaya, an MBA and a Ph.D. from the University of South Carolina. He has published articles in academic journals such as Journal of Operations Management, Decision Sciences, Interfaces, Journal of Management, European Journal of Operational Research, and International Journal of Production Research, among others. His current research interests include supply chain management, international operations, operations strategy, and technology management. He has co-authored three books, won research and teaching awards, and received an Educator of the Year award from the Asian Chamber of Commerce in Las Vegas. He has held leadership positions in Decision Sciences Institute such as Editor of Decision Line, At-Large Vice-President, Chair of the Innovative Education Committee, Chair of the Doctoral Student Affairs Committee, and Manufacturing Management Track Chair.

Keah-Choon Tan is Associate Professor of Operations Management at the University of Nevada Las Vegas. He received his Ph.D. in Production and Operations Management from Michigan State University. He has published articles in the areas of supply chain management, quality and operations scheduling in a number of trade magazines and academic journals, including Decision Sciences, European Journal of Purchasing and Supply Management, International Journal of Operations and Production Management, International Journal of Production Research, Journal of Supply Chain Management, Omega, and Quality Management Journal. He is a coauthor of the Principles of Supply Chain Management: A Balanced Approach. Dr. Tan is the executive editor of the International Journal of Integrated Supply Management, co-guest editor of a special issue of the International Journal of Internet and Enterprise Management, and he also serves on the editorial board of the Industrial Management and Data Systems Journal. 


\title{
SUPPLIER SELECTION CONSTRUCT: INSTRUMENT DEVELOPMENT AND VALIDATION
}

\begin{abstract}
The importance of supplier selection is well established in the literature. However, while the criteria and processes used by supply managers to evaluate key suppliers have been researched extensively, little has been done to meticulously conceptualize and measure the underlying construct of supplier selection. This study proposes that supplier selection can be adequately represented by a three-factor construct that reflects buyer assessment of supplier quality and service, and the strategic/management fit between a buyer and supplier. The supplier selection construct was tested using samples drawn from the U.S. and Europe. Statistical analysis shows that both samples supported the three-factor supplier selection construct.
\end{abstract}

Key words: supplier selection, supply chain management, instrument development, structural equation model. 


\section{INTRODUCTION}

Effective supplier selection plays a vital role in creating a competitive edge for a firm and in having a positive impact on its performance. Not surprisingly therefore, the literature on supplier selection is extensive, consisting of both empirical studies of actual practice and prescriptive studies of how suppliers should be selected ${ }^{1}$. However there remains ambiguity over what exactly constitutes effective supplier selection and what are the appropriate measures for selecting key suppliers. While supplier selection has been examined in a number of different contexts, no common definition of it is evident from the literature. Moreover, while there has been considerable interest in supplier selection from academics and practitioners, no attempt has been made to develop a valid measure of supplier selection.

The supplier selection literature can be characterized as overly simplistic due to the use of single item measurement scales. The result is that practitioners lack guidance when making supplier selection decisions. While supply managers are faced with a multitude of selection criteria, there is no way for managers to know which measures are valid indicators of a supplier's ability to service their needs. As firms increasingly allocate resources to their core competencies and encourage both domestic and international outsourcing of non-core activities, it is important for them to be able to focus their assessment of suppliers on factors likely to lead to successful purchase outcomes, and to be able to do so regardless of the geographic location of the buyer or supplier. From an academic perspective, the lack of a common measure of supplier selection

\footnotetext{
${ }^{1}$ Several analytic models of supplier selection have also been proposed. These however do not address the underlying issue of selection criteria and are thus beyond the scope of the current study.
} 
means that the results of supplier selection studies are often difficult to compare since different studies operationalize supplier selection differently.

The need exists for the development and testing of a reliable and valid supplier selection measurement scale that can be applied in different geographic regions. To accomplish this, a set of multi-item scales were developed based on a review of prior literature, input from senior supply managers, and actual company supplier selection manuals. The research was done in the context of strategically important suppliers rather than suppliers of commodities for which supplier selection is likely to focus on short-term price/cost tradeoffs. While the difference may appear trivia, savvy industrial buyers and merchants focus on the total cost of acquisition, and the capability and technology of strategic suppliers in enhancing their competitive advantage. Structural equation modeling was used to test a three-factor supplier selection construct against a survey sample drawn in the U.S. The scales and supplier selection construct were further validated by a second survey sample drawn in Europe.

The remainder of the paper is organized as follows. The next section provides a review of the literature. This is followed by a description of the conceptual framework, and a methodology section that presents the instrument development and details of the statistical analysis. Then the results of the study are presented. Finally, managerial implications and conclusion of the research are provided.

\section{LITERATURE REVIEW}

Supplier selection is a crucial process that addresses how organizations select strategic suppliers to enhance their competitive advantage. Depending on the purchase context, it may also address whether the strategic goals and management philosophies of the buyer and supplier are congruent. For example, the needs of a buyer emphasizing quality and long-term growth may 
not be well served by a supplier emphasizing short-term profit at the expense of quality. A number of themes emerge from prior literature, which evolved primarily from the purchasing and supply management domain. Much of the early work that focuses on the purchase environment (Table 1) takes a transactional approach to study the underlying criteria used to select suppliers in different purchase situations [1][2]. While a number of selection criteria have been identified, there is significant variation between studies and in the relative importance of the specific criteria under different scenarios. For example, buyers are more likely to focus on quality, technology, capability and service in capital investment and sourcing of crucial production materials, whereas cost/price may be the most important criterion in commodity purchases. Nonetheless, general themes of quality, delivery, price of materials and services, responsiveness, and service $[3][4][5][6]$ consistently emerge. The second theme focuses on the strategic issues and examines the strategic implications of supplier selection. The advent of supply chain management as a business paradigm has fundamentally reshaped the role of supplier selection. Manufacturing firms are shifting away from vertical integration toward developing smaller, leaner organizations that focus on exploiting core competencies [7]. This has led to companies reducing the size of their supplier bases so they can more effectively manage relationships with, and more efficiently leverage capabilities and technologies of strategic suppliers [8]. It has also led to traditional adversarial buyer-supplier relationships being gradually replaced with mutually beneficial partnership relationships, particularly with strategically important suppliers who can positively affect buyer's competencies [9][10]. Pertinent empirical studies again point to the importance of quality, cost, delivery, and service. However, they also stress the need to examine a broader set of criteria. In particular, they highlight the need to look at intangibles such as goal alignment between buyer and supplier, and supplier capability [3][11]. A third, more recent stream of 
research focuses on the performance issues and examines the impact of supplier selection on measures of the buying firm's performance. Of particular significance is the fact that not only does supplier selection impact both manufacturing and business performance, more commonly used criteria such as cost and quality may have less impact on performance than intangible criteria discussed above [3][11]. The implication is that factors such as quality, cost, delivery, and service can have an undue bearing on selection decisions. The extensive list of supplier selection research makes it a daunting task to summarize the findings of the literature. Table 1 shows a list of the literature that discussed relevant issues of supplier selection.

\section{Insert Table 1}

As firms become more reliant on their strategic suppliers, it becomes increasingly important that they select the right suppliers for their needs. The difficulty they face is that despite the extensive literature on supplier selection, there is no consensus regarding which selection criteria are the most important. The underlying characteristics of supplier selection are abstract and inherently difficult to measure, adding to the difficulty. Our review of the literature indicates a lack of consensus in providing definitive guidance to supply managers involved in strategic purchasing. As a result, supply managers often resort to establishing a set of criteria to evaluate and compare potential sources each time a purchase situation arises [3]. However, this makes supplier selection context specific and makes it difficult to standardize selection processes. In addition, it means there is wasted effort when the process is repeated for each purchase occurrence. The lack of commonality also hinders the development of frameworks to guide practitioners, while the absence of reliable and valid measurements makes it difficult to directly compare different research studies. 


\section{CONCEPTUAL FRAMEWORK}

Theoretical basis for the construct of supplier selection can be derived from transaction cost economics and the resource based view of the firm. The underlying premise of transaction cost economics is that firms are driven by the objective of profit maximization [12][13][14][15]. In the context of sourcing decisions, it is the relative cost of using markets as opposed to firm controlled resources that drive resource allocation decisions. Moreover, firms realize cost efficiencies when there is congruence between their governance structure and attributes of the underlying transactions [13][14][15]. Firms that source internally do so to minimize costs, safeguard transaction specific investments, and adapt to environmental uncertainty associated with transactions [16][17][18]. It also allows them to avoid supplier opportunism. Recent research however challenges basic assumptions underlying the theory and suggests that relationships between buyers and suppliers lower transaction costs and facilitate investments in relation-specific assets [19][20][21][22][23]. If a supplier can produce at lower cost than the buyer and the differential is greater than the sum of transaction related costs, external sourcing is preferred. Transaction costs however depend not on the quantity or variety or products but on the ability of the supplier to meet buyer expectations. If there is a mutually beneficial relationship between buyer and suppliers, opportunism will no longer be a concern for the buyer even when highly specific assets are involved. The result is that firms can gain complementary skills by leveraging their collective expertise, capabilities, and willingness to share risk.

The resource-based view of the firm suggests that gaining and preserving sustainable competitive advantage is a function of the core resources and capabilities each organization can leverage in a given situation [24], and that such resources and capabilities are the primary source 
of an organization's success [25]. Decisions regarding the locus of control of resources should be made on the basis of whether external entities, as opposed to the firm, have unique resources that represent a source of competitive advantage [26][27]. From a sourcing perspective, the implication is that how firms acquire materials and services has a profound bearing on their ability to meet their customer's needs and create sustainable value.

As these theories suggest, a firm's ability to create a competitive advantage depends in part on its ability to effectively manage sourcing decisions. This in turn implies the need to select suppliers based on their ability to support value creation efforts. At the core of this is the ability of suppliers to not only meet buyer needs in terms of product and performance, but also alignment of the goals and objectives of both parties. Based on a review of the literature and actual supplier selection practices derived from company manuals, and discussions with supply management professionals, we operationalize supplier selection in terms of three constructs consistent with existing theory; supplier quality, supplier service, and the strategic/management fit between buyer and seller (Figure 1). The specific indicators of each construct and support for them from the literature are presented in Table 2.

\begin{tabular}{c}
\hline Insert Figure 1 \\
Insert Table 2 \\
\hline
\end{tabular}

\section{Supplier Quality}

Several studies have attempted to identify the underlying dimensions of quality management and to relate them to organizational success. For example, a theory of quality deployment based on Deming's philosophy demonstrated that visionary leadership, internal and external cooperation, process management, and employee fulfillment are drivers of customer 
satisfaction [28][29]. Subsequent research tested and found support for the proposition that strategic quality management, as embodied in similar constructs affects performance, either in terms of product quality [30][31], broader measures of manufacturing performance [32][33] or business performance [34][35]. In addition to the evidence that strategic quality management affects performance, recent studies also suggest that the effective deployment of quality tools affects business performance [34][36].

Supplier quality has consistently been identified as a key supplier selection criterion [3]. Moreover, it has long been considered an important component in building strategic buyersupplier partnerships. Several quality management models have also proposed that supplier quality is a key element of a successful quality management program [30][37][38]. Additional support that cost/price is not the over-riding criterion in supplier selection is provided in a study of the electronics industry by Pearson and Ellram [39] that showed that quality was the most important criteria due to its strategic importance. While the specific definition of quality may vary depending on the purchase context, it is inevitable that quality will be a key determinant in any purchase decision. This study therefore theorizes that supplier quality is an important facet of supplier selection. In accordance with [40], seven observed indicators of a supplier quality focus were identified; supplier testing capability, scope of resources, technical expertise, industry knowledge, commitment to quality, supplier's process capability, and commitment to continuous improvement in product and process (Table 2).

\section{Supplier Service}

The supplier selection research has also highlighted the importance of a supplier being able to meet buyer needs. There are two facets to this. First, suppliers should have the ability to meet buyer demand in a timely manner and respond rapidly to changes in demand. Not only does 
the supplier selection literature speak of the importance of delivery service [3], the literature on supply chain management and time-based competition also emphasize the importance of supplier responsiveness to changing buyer needs, particularly in an environment characterized by short product life cycles and downward pressure on product lead times [41]. Second, the supplier should be able to do so in a manner consistent with price expectations of the buyer. This is consistent with empirical evidence that suggests the price of materials and services is a crucial factor in selecting suppliers [3]. Suppliers who wish to establish a long term, mutually beneficial partnership with a buyer should not charge a premium for providing enhanced services in response to changing buyer needs. Moreover, in a partnership environment, the price of key materials and services are often negotiated and is only one of several factors affecting supplier selection. Total cost of ownership that considers other aspects of acquisition and service delivery is a more appropriate selection criterion. Five indicators are used to measure supplier service; supplier ability to meet delivery due dates, the price of materials, parts and services, flexible contract terms and conditions, geographical proximity, and reserve capacity or the ability to respond to unexpected demand (Table 2).

\section{Strategic/Management Fit}

Firms are more reliant on suppliers than ever and increasingly adopt a supply chain perspective in managing material flows. These factors imply the need for greater alignment between buyer and supplier, and in particular, in terms of their strategic/management fit [42]. This facet of supplier selection examines whether the strategic goals and management philosophies of the buyer and supplier are congruent. For the purpose of this research, strategic fit is defined in terms of whether the buyer and supplier act in a unified manner toward a desired strategic goal. Management fit is defined in terms of whether each entity seeks to understand the 
desires and goals of the other and to appreciate the situation from the other's perspective. For example, a firm emphasizing low cost, high-volume production that competes primarily on price is unlikely to find a good fit with a supplier that emphasizes leading edge technology and product innovation. Management fit also encompasses whether there is a cultural match between the firms, a necessary ingredient for successful buyer-seller partnerships [43][44][45]. An important element in developing successful buyer-supplier partnerships is trust. Several researchers have studied trust in the context of buyer-supplier relationships [45][46][47][48]. A lack of trust between supply chain partners causes inefficiencies, which can lead to poor performance [48]. Moreover, effective communication with suppliers, which can result from increased trust, has an impact on performance especially in a just-in-time environment [49]. However, a less frequently discussed facet of trust is how the increasing levels of supplier and/or buyer power affect trust among members of the supply chain. A very powerful trading partner is obviously able to exert pressure on members of the supply chain.

While the supplier selection literature has tended to focus on more tangible, measurable criteria, intangible criteria such as strategic/management fit have been shown to impact the long term success of buyer-supplier relationships [1] as well as the overall success of the buying firm [3]. An exploratory study also showed that a powerful buyer can damage the organizational health of a submissive supplier where there is a clear lack of cultural alignment between the buyer and supplier [50]. Given the focus of this study on strategically important suppliers, strategic/management fit is of particular relevance. Eight observed indicators are used to measure the strategic/management fit between buyer and supplier; the extent to which the supplier is open to site evaluation, supplier references and reputation, the supplier's financial stability and staying power, honest and frequent communications between buyer and supplier, the cultural match 
between the firms, past and current relationships with the supplier, the strategic importance of the supplier, and the supplier's willingness to share confidential information (Table 2).

\section{METHODOLOGY}

Figure 2 outlines the two-step procedure used to develop the survey instrument and to test the supplier selection construct. The first step, measure development and pre-test, was used to develop and validate the survey instrument, while the second step, two-stage main survey procedure, was used to test and validate the research construct.

\section{Insert Figure 2}

\section{Questionnaire Development and Pre-Test}

Questions were developed for each indicator using five point Likert scales. Questions were worded and ordered with the goal of minimizing the risk of common method bias. This was particularly important since cost precluded soliciting more than one response from the same firm. In addition, care was taken to ensure a high degree of content validity. To accomplish this, the questionnaire was designed with the assistance of a few well-published researchers in the field and two senior managers from two large, technologically advanced companies in the U.S. The companies also provided their supplier selection manuals for our reference, but asked to remain anonymous. Then, ten senior supply managers with extensive experience and knowledge of supplier selection were asked to assess the items and to suggest how to reword them, as necessary, to improve clarity and validity. The revised survey was pre-tested by a group of twenty senior supply managers who were asked to complete the survey and to identify any concerns they had. Where necessary, the survey instrument was again revised. Responses from the thirty pilot study and pre-test questionnaires were not used for subsequent analyses. 


\section{Two-Stage Main Survey Procedure}

The main survey procedure consisted of two stages. A survey was first conducted to further refine the survey instrument and to explore the plausibility of the research construct. This was followed by a second survey to confirm and test the validity of the research construct across national boundaries. In the first survey, 1,500 questionnaires were mailed to senior supply managers in the U.S. identified from the Institute for Supply Management (ISM) membership list. The original mailing consisted of the questionnaire and a postage-paid return envelope. A reminder postcard was mailed two weeks later, followed by a duplicate questionnaire and postage-paid return envelope two weeks thereafter. This sample yielded one hundred useable surveys returned (6.7\% response rate), and is referred to as ISM-US. There was a spur of empirical research in supply chain management from the mid 1990s to early 2000s where researchers targeted their surveys toward ISM members because of the free membership list available from the organization. The overuse of the ISM sampling frame may account for the lower than expected response rate because. However, since the research model was further tested by two additional samples, the response rate for the exploratory sample is not a serious concern.

In the second stage, data for model confirmation and cross-validation was obtained by sending the refined survey instrument to 2,982 members of the Association for Operations Management (APICS) in the U.S., and 970 members in Europe. Again, two questionnaires and a reminder postcard, mailed two weeks apart, were used to solicit responses. A total of 310 useable surveys from the U.S. (10.4\% response rate) and 115 from Europe (11.9\% response rate) were received. These response rates are comparable to those of other empirical supply chain management studies that used similar membership mailing lists [51][52][53]. The U.S. and European samples are called APICS-US and APICS-Europe respectively. 
To test for common method variance, the Harman one-factor method was used [54]. If common method bias is a serious problem, either a single factor will emerge or a general factor will account for most of the variance in the data. Since principal components factor analysis of the data yielded 3 factors, each with eigenvalues greater than 1.0, we concluded that common method bias [55] was not present. To test for non-response bias, responses of early respondents were compared to those of late respondents [56][57]. $\chi^{2}$ tests showed that no significant differences existed in responses to questions on demographic characteristics. T-tests also indicated no significant differences in responses to ten randomly selected questions regarding supplier selection variables. Table 3 describes the characteristics of the responding firms, while Table 4 summarizes responses for the three samples. Data suggest that the three samples are comparable in terms of the distributions of firms based on industry, size, and annual sales.

Insert Table 3

Insert Table 4

\section{RESULTS}

\section{Exploratory Analyses of the ISM-US Sample}

Psychometric properties of the survey instrument were evaluated using data from the ISM-US sample. Construct validity is concerned with the appropriateness of the underlying structure of a construct [58] and can be assessed by determining the empirical dimensions of the construct using principal components factor analysis. Exploratory methods were used since there is no existing theory regarding the coexistence of factors in a supplier selection model, and this study represents initial empirical work done on the three proposed factors. Reliability analysis 
was carried out using Cronbach's $\alpha$ [59] to assess the validity of the three scales. Values of $\alpha$ in excess of 0.50 indicate that given the exploratory nature of the analysis, the scales can be considered reliable [60]. Principal components analysis was conducted to extract factors with eigenvalues of at least one [61]. Only items with factor loadings in excess of 0.50 were included. A scree plot was also used to further verify the number of factors to be included in the final solution. These techniques yielded three factors corresponding to the hypothesized factors supplier quality, service, and strategic/management fit (Table 5). One item, open to site evaluation, did not have the required factor loading and was omitted from the survey and from further analysis. The remaining items had factor loadings of between 0.58 and 0.79 on their respective factors. Both convergent and discriminant validity are considered subcategories or subtypes of construct validity. Instead of testing convergent and discriminant validity individually, in our manuscript, we tested the construct validity as a whole. Churchill [62] suggests that construct validity of a measure should be validated with new data and Kerlinger [63] believes that construct validity requires preoccupation of theoretical constructs and scientific empirical inquiry and it is necessary to test the construct validity of the measure with additional data. Therefore, following their suggestion, we employ ISM-US data to develop the construct and use APICS-US and APICS-Europe data to test the construct validity. This validation process (validating construct validity with additional new data, not testing convergent/discriminant validity individually) has been widely used in scale development in the marketing literature [64].

Insert Table 5 
Lisrel 8-Simplis was used to analyze the hypothesized three-factor supplier selection construct [65][66]. A two-step model-building approach was used whereby the measurement models were tested prior to the first-order confirmatory factor analysis (CFA) model [67]. One measured variable in the supplier quality factor, technical expertise, exhibited large error variance, indicating that it is unimportant to the model [65]. It was thus deleted from the model. The revised supplier quality measurement model exhibited good model fit. Its $\chi^{2}$ p-value was non-significant $(\mathrm{p}=0.26)$ and the ratio of $\chi^{2}$ to degrees of freedom $\left(\chi^{2} / \mathrm{d}\right.$.f. $\left.=1.257\right)$ was below the recommended value of 3 . Values for other commonly used measures of model fit were also in excess of their respective recommended values (Figure 3). All parameter values for individual indicators were statistically different from zero (Figure $3, \alpha=0.05$ ). The supplier service model also exhibited good fit with the data. Its $\chi^{2}$ value was again non-significant $(\mathrm{p}=0.06)$ and the ratio of $\chi^{2}$ to degrees of freedom $\left(\chi^{2} /\right.$ d.f. $\left.=2.00\right)$ was lower than the recommended value. Other measures of model fit (see Figure 3) were again in excess of their recommended values and all indicator parameter values were statistically different from zero. The Strategic/Management Fit measurement model also exhibited good model fit (see Figure 3). While one measure of fit, NFI, was marginally below its required value of 0.90 , the ratio of $\chi^{2}$ to degrees of freedom $\left(\chi^{2} / \mathrm{df}=\right.$ 1.589) as well as remaining measures of model fit suggested that the model fit the data well and parameter values for individual indicators were also significant.

\section{Insert Figure 3}

Having tested the measurement models individually, they were tested together using confirmatory factor analysis (Figure 4, Exploratory ISM-US model). All model fit indices suggested that the data fit the supplier selection model well. Not only was the ratio of $\chi^{2}$ to 
degrees of freedom below $3\left(\chi^{2} /\right.$ d.f. $\left.=2.087\right)$, values for other measures of model fit were above the recommended value of 0.90. Parameter estimates, fit indices, and observed residuals all suggested that the ISM-US model exhibited good fit for the observed correlations among the respective model items and latent variables. Fit statistics also suggested that each scale captured a significant amount of variation in the three latent dimensions.

\section{Insert Figure 4}

\section{Confirmatory Analyses of the APICS-US and APICS-Europe Samples}

Based on the results of the exploratory analysis, the survey instrument was modified and the revised instrument mailed to a larger sampling group (APICS-US and APICS-Europe). Data gathered was used to validate the proposed three-factor supplier selection construct and to test its validity across national boundaries. The APICS-US data was first used to validate the measurement models and the corresponding first-order confirmatory factor analysis model derived from the ISM-US data (Figure 5). All three measurement models exhibited good model fit. $\chi^{2}$ values were non-significant $\left(\mathrm{p}=0.06,0.05\right.$, and 0.13 , respectively) and ratios of $\chi^{2}$ to degrees of freedom were less than $3\left(\chi^{2} / \mathrm{df}=1.891,2.380\right.$, and 1.493 , respectively). Remaining fit indices also suggested the data fit the measurement models well. The confirmatory model (Figure 4, Confirmatory APICS-US) indicated that the APICS-US data fit the first-order CFA model well. With only one exception, all goodness of fit indices met the recommended standard, and all parameter values were statistically different from zero. The results thus provide support for the proposed three-factor supplier selection construct in the U.S. 


\section{Insert Figure 5}

To test the validity of the three-factor supplier selection construct in Europe, it was tested using the APICS-Europe data. Fit indices for the measurement models all met the respective standards for good fit and indeed demonstrated better fit than for the two samples drawn from the U.S (Figure 6). All parameter values were again statistically significant. Similar results were observed for the CFA model, suggesting that the data from Europe fit the three factor supplier selection construct well (Figure 4, Confirmatory APICS-Europe).

\section{Insert Figure 6}

\section{MANAGERIAL IMPLICATIONS AND CONCLUSION}

In an era characterized by increasing quality, delivery, and cost pressures, firms need more than ever to get it right when managing supply processes. At the same time, they are also recognizing the value of relinquishing some control over these processes. The result is that it is imperative that they select the right suppliers to meet their needs. While past studies have identified individual criteria that can be used to screen and select potential suppliers, they have not identified the underlying dimensions of supplier selection. Through a rigorous, analytic process, this study demonstrates that underlying the documented supplier selection criteria is the need to assess a supplier's quality and service capabilities as well as their strategic and managerial alignment with the buyer. While these can be defined and measured in different ways, it is important to recognize that they represent what buyers' need to critically evaluate when making purchase decisions. This study provides supply management professionals with 
guidelines for analyzing selection decisions, and also shows that the underlying dimensions of supplier selection are applicable for both American and European firms.

While seemingly subtle, an important additional finding is that the price of materials and services is an indicator of supplier service rather than being a separate factor. This is consistent with price no longer being an order winner but an order qualifier in a highly competitive global environment. It is also consistent with the fact that with strategic purchases, buyers are looking beyond price, with the ability to create value and contribute to generating competitive advantage being a more critical consideration. With increasing emphasis on cost reduction initiatives over the course of a long term contact, negotiated price takes on less significance in supplier selection than the ability of the supplier to work with the buyer to help achieve their shared objectives.

The study is not without its limitations. While the research design incorporated prior literature and expert opinion, the nature of empirical study implies that the study cannot capture every aspect of the supplier selection process. Establishment of a valid, reliable supplier selection instrument is an ongoing process and no psychometric technique can adequately address the completeness or breadth of measurement. It is entirely possible that other dimensions of supplier selection exist but are not conceptualized in the proposed model. The nature of the samples utilized in this analysis is another concern. The focus of this study was on a diverse group of well-established, medium and large sized companies. Such companies are likely to have well defined selection criteria and supply management personnel with a vested interest in building relationships with key suppliers. While the sampling frames contain firms representative of a large proportion of the economic base and who would tend to be more discriminating in their supplier selection protocols, the results cannot be generalized to, for instance, smaller companies or those with less sophisticated supply management practices. Moreover, the results 
cannot be generalized to firms having unique product or industry related purchasing characteristics. A third limitation is the sample sizes used. While the models developed were found to converge and to be statistically valid, the number of observations obtained was on the low side of what is typically observed in structural equation models. Although limitations attributable to sample size do not seem particularly threatening, it would be inappropriate not to recognize their potential impact.

While this study has provided theoretical substance to the discussion of supplier selection, it has by no means answered all questions concerning this problem. A potential avenue for future research is to replicate the study across a broader sampling frame. Contingent analysis by firm size, industry, or geographic region where samples are also obtained in environments with different cultural norms and degrees of purchasing maturity, would either provide additional validity for the current findings or show them to be unique to the specific experimental conditions. Another area for future inquiry concerns the evolution of supplier selection over time. In other words, how do supplier selection practices evolve as buyer-supplier relationships mature? This is of particular interest given the shift towards more cooperative buyer-supplier relationships. Although the results of the current study imply that supplier selection should focus on quality, service, and strategic/managerial fit, conclusions cannot be drawn regarding the relative importance of these over time and as environmental conditions change. 


\section{REFERENCES}

[1] Ellram LM. The supplier selection decision in strategic partnerships. Journal of Purchasing and Materials Management 1990; 26(1): 8-15.

[2] Swift CO. Preferences for single sourcing and supplier selection criteria. Journal of Business Research 1995; 32(2): 105-111.

[3] Kannan VR, Tan KC. Supplier selection and assessment: their impact on business performance. Journal of Supply Chain Management 2002; 38(4): 11-22.

[4] Dickson GW. An analysis of supplier selection systems and decisions. Journal of Purchasing 1996; 2: 5-17.

[5] Verma R, Pullman ME. An analysis of the supplier selection process. Omega: International Journal of Management Science 1998; 26(6): 739-750.

[6] Wilson EJ. The relative importance of supplier selection criteria. International Journal of Purchasing and Materials Management 1994; 35-41.

[7] Prahalad CK, Hamel G. The core competence of the corporation. Harvard Business Review; 1990 68(3); 79-91.

[8] Tully S. Purchasing's new muscle. Fortune; 1995 (20): 76.

[9] Copacino WC. Seven supply chain principles. Traffic Management 1996; 35(1): 60.

[10] Mason T. Getting your suppliers on the team. Logistics Focus 1996; 4(1): 10-12.

[11] Vonderembse MA, Tracey M. The impact of supplier selection criteria and supplier involvement on manufacturing performance. Journal of Supply Chain Management, 1999; 35(3): 33-39.

[12] Coase RH. The nature of the firm. Economica 1937; 4: 386-405.

[13] Williamson, OE. Markets and hierarchies: Analysis and antitrust implications. New York: Free Press, 1975.

[14] Williamson OE. The economics of organization: The transaction cost approach. American Journal of Sociology, 1981; 87: 548-77.

[15] Williamson, OE. The economic institutions of capitalism. New York: Free Press, 1985.

[16] Heide JB. Inter-organizational governance in marketing channels. Journal of Marketing, 1994; 58: 781-85.

[17] Heide J, John G. The role of dependence balancing in safeguarding transaction-specific assets in conventional channels. Journal of Marketing, 1988; 52: 20-35.

[18] Rindfleisch A, Heide JB. Transaction cost analysis: Past, present, and future applications. Journal of Marketing, 1997; 61: 30-55.

[19] Dyer JH. Specialized supplier networks as a source of competitive advantage: Evidence from the auto industry. Strategic Management Journal 1996; 17(4): 271-291. 
[20] Heide J, John G. Alliances in industrial purchasing: The determinants of joint action in buyer-supplier relationships. Journal of Marketing Research 1990; 27(1): 24-36.

[21] Hill, WL. Cooperation, Opportunism, and the Invisible Hand: Implications for Transaction Cost Theory. Academy of Management Review 1990; 15: 500-513.

[22] Walker G, Poppo, L. Profit Centers, Single Source Suppliers, and Transaction Costs. Administrative Science Quarterly 1991; 36(1): 66-87.

[23] Zaheer A, McEvily B, Perrone V. The strategic value of buyer-supplier relationships. International Journal of Purchasing and Materials Management 1998; 34(3): 20-26.

[24] Barney, JB, Looking inside competitive advantage. Academy of Management Executive, 1995; 9(4): 49-61.

[25] Grant, RM. The resource-based theory of competitive advantage: Implications for strategy formulation. California Management Review, 1991; 33(3): 114-135.

[26] McWilliams A, Gray S. Understanding quasi-integration. Journal of Business Strategies, 1995; 12: 69-85.

[27] Poppo L, Zenger T. Testing alternative theories of the firm: Transaction cost, knowledgebased, and measurement explanations for make-or-buy decisions in information services. Strategic Management Journal, 1998; 19: 853-877.

[28] Anderson JC, Rungtusanatham M, Schroeder RG. A theory of quality management underlying the Deming management method. Academy of Management Review 1994; 19(3): 472-509.

[29] Anderson JC, Rungtusanatham M, Schroeder RG, Devaraj S. Path analytic model of a theory of quality management underlying the Deming management method: preliminary empirical findings. Decision Sciences 1995; 26(5): 637-658.

[30] Ahire SL, Golhar DY, Waller MA. Development and validation of TQM implementation constructs. Decision Sciences 1996; 27(1): 23-56.

[31] Dow D, Samson D, Ford S. Exploding the myth: Do all quality management practices contribute to superior quality performance? Production and Operations Management 1999; 8(1): 1-27.

[32] Flynn BB, Schroeder RG, Sakakibara S. The impact of quality management practices on performance and competitive advantage. Decision Sciences 1995; 26(5): 659-692.

[33] Samson D, Terziovski M. The relationship between total quality management practices and operational performance. Journal of Operations Management 1999; 17: 393-409.

[34] Kannan VR, Tan KC, Handfield RB, Ghosh S. Tools and techniques of quality management: an empirical investigation of their impact on performance. Quality Management Journal 1999; 6(3): 34-49.

[35] Powell T. Total quality management as competitive advantage: a review and empirical study. Strategic Management Journal 1995; 16: 15-37.

[36] Handfield RB, Jayaram J, Ghosh S. An empirical examination of quality tool deployment patterns and their impact on performance. International Journal of Production Research 1999; 37(6): 1403-1426. 
[37] Black SA, Porter LJ. Identification of the critical factors of TQM. Decision Sciences 1996; 27: $1-22$.

[38] Flynn BB, Sakakibara S, Schroeder RG. Relationship between JIT and TQM: practices and performance. Academy of Management Journal 1995; 38(3): 1325-1360.

[39] Pearson J., Ellram L. Supplier selection and evaluation in small versus large electronics firms. Journal of Small Business Management 1995; 33(4): 53-65.

[40] Churchill GA Jr. A paradigm for developing better measures of marketing constructs. Journal of Marketing Research 1979; 16: 64-73.

[41] Vickery S, Calantone R, Dröge C. Supply Chain Flexibility: An Empirical Study. Journal of Supply Chain Management 1999; 35(3): 16-24.

[42] Spekman RE. Strategic supplier selection: Understanding ling term relationships. Business Horizons 1988; 31(4): 75-81.

[43] Kanter, R.M. Becoming PALs: Pooling, Allying and linking across companies. Academy of Management Executive 1989; 3(3): 183-193.

[44] Burnes B, New S. Collaboration in customer-supplier relationships: Strategy, operations and function of rhetoric. International Journal of Purchasing and Management 1997; 33(4): $10-18$.

[45] Boddy D, Cahill C, Charles M, Fraser-Kraus H, Macbeth D. Success and failure in implementing supply chain partnering: An empirical study. European Journal of Purchasing and Supply Chain Management 1998; 4(2-3): 143-151.

[46] Doney PM, Cannon JP. An examination of the nature of trust in buyer-seller relationships. Journal of Marketing 1997; 61(2): 35-51.

[47] Smeltzer L. The meaning and origin of trust in buyer-supplier relationships. The Journal of Purchasing and Materials Management1997; Winter: 40-48.

[48] Kwon IG, Suh T. Factors affecting the level of trust and commitment in supply chain relationships. Journal of Supply Chain Management 2004; Spring: 4-14.

[49] Richeson L, Lackey C Jr., Starner JW Jr. The effect of communication on the linkage between manufacturers and suppliers in a just-in-time environment. International Journal of Purchasing and Materials Management 1995; 31(1): 20-25

[50] McHugh M, Humphreys P, McIvor R. Buyer-supplier relationships and Organizational health. The Journal of Supply Chain Management 2003; 39(2): 15-25.

[51] Fawcett, S.E., Magnan, G.M. (2001). Achieving World-Class Supply Chain Alignment: Barriers, Bridges, and Benefits. Center for Advanced Purchasing Studies (CAPS) Focus Study, Center for Advanced Purchasing Press: Tempe, AZ.

[52] Frohlich, M.T., and Westbrook, T. (2001). Arcs of Integration: An International Study of Supply Chain Strategies. Journal of Operations Management, Vol. 19, No. 2, pp. 185-200.

[53] Morash, E.A., and Clinton, S.R. (1998). Supply Chain Integration: Customer Value Through Collaborative Closeness Versus Operational Excellence. Journal of Marketing Theory and Practice, Vol. 6. No. 4, pp. 104-120. 
[54] Podsakoff, P.M., Organ, D.W. (1986). Self-Reports in Organizational Research: Problems and Prospects, Journal of Management, 12 (4), 531-44.

[55] Menon, A., Bharadwaj, S.G., Adidam, P.T., Edison, S.W. (1999), Antecedents and Consequences of Marketing Strategy Making: A Model and a Test, Journal of Marketing, 63(2), 18-40.

[56] Armstrong JS, Overton TS. Estimating non-response bias in mail surveys. Journal of Marketing Research 1977; 14(3): 396-402.

[57] Lambert DM, Harrington TC. Measuring non-response bias in mail surveys. Journal of Business Logistics 1990; 11(2): 5-25.

[58] Carmines EG, Zeller RA. Reliability and validity assessment. Thousand Oaks: Sage, 1979.

[59] Cronbach LJ. Coefficient alpha and the internal structure of tests. Psychometrika 1951; 16: 297-334.

[60] Nunnally JC. Psychometric Theory. New York: McGraw-Hill, 1988.

[61] Bernstein IH. Applied multivariate analysis. New York: Springer-Verlag, 1988.

[62] Churchill, G.A. Jr. A paradigm for developing better measures of marketing constructs. Journal of Marketing Research 1979; 16 (Feb): 64-73.

[63] Kerlinger, F.N. Foundations of behavioral research, New York, Holt, Rinehard and Winston; 1986.

[64] Li, H, Edwards, S.M., Lee, J.H. Measuring the intrusiveness of advertisements: Scale development and validation. Journal of Advertising 2002; 31(2): 37-47.

[65] Byrne BM. Structural equation modeling with Lisrel, Prelis, and Simplis: basic concepts, applications, and programming. Mahwah: Lawrence Erlbaum Associates, 1998.

[66] Jöreskog KG, Sörbom D. LISREL8: structural equation modeling with the SIMPLIS command language. Hillsdale: Lawrence Erlbaum Associates, 1993.

[67] Anderson JC, Gerbing DW. Structural equation modeling in practice: a review and recommended two-step approach. Psychological Bulletin 1988; 103(3): 411-423.

[68] Min H, Galle WP. Green purchasing strategies: Trends and implications. International Journal of Purchasing and Materials Management 1997; 33(3): 10-17.

[69] Cavusgil ST, Yavas U. Supplier selection in international markets: A study of Saudi importers. Industrial Marketing and Purchasing 1987; 2(2): 19-28.

[70] Deng S, Wortzel LH. Importer purchase behavior: Guidelines for Asian exporters, Journal of Business Research 1995; 32(1): 41-47.

[71] Katsikeas CS, Leonidou LC. International supplier selection: The relevance of import dependence, Journal of Global Marketing 1996; 9(3): 23-45.

[72] Min H, Galle WP. International purchasing strategies of multinational U.S. firms. International Journal of Purchasing and Materials Management 1991; 27(3): 9-18. 
[73] Piercy NF, Katsikeas CS, Cravens DW. Examining the role of buyer-seller relationships in export performance. Journal of World Business; 1997, 32(2): 73-86.

[74] Sharland A, Eltantawy RA, Giunipero LC. The impact of cycle time on supplier selection and subsequent performance outcomes. Journal of Supply Chain Management 2003; 39(3): 4-12.

[75] Cusumano MA, Takeishi A. Supplier relations and management: A survey of Japanese, Japanese-transplant, and U.S. auto plants. Strategic Management Journal 1991; 12(8): 563588.

[76] Gustin CM, Daugherty PJ, Ellinger AE. Supplier selection decisions in systems/software purchases. International Journal of Purchasing and Materials Management 1997; 33(3): 4146.

[77] Helper S. How much has really changed between US automakers and their suppliers. Sloan Management Review 1991; 32: 15-28.

[78] Hirakubo N, Kublin M. The relative importance of supplier selection criteria: The case of electronic components procurement in Japan. International Journal of Purchasing and Materials Management 1998; 34(2); 19-24.

[79] Lambert DM, Adams RJ, Emmelhainz MA. Supplier selection criteria in the healthcare industry: A comparison of importance and performance. International Journal of Purchasing and Materials Management, 1997; 33(4): 16-22.

[80] Pearson JN, Ellram LM. Supplier selection and evaluation in small versus large electronics firms. Journal of Small Business Management 1995; 33(4): 53-65.

[81] Abratt, R. Industrial buying in high tech markets. Industrial Marketing Management 1986; 15(4): 293-298.

[82] Karande K, Shankarmahesh MN, Rao CP. Marketing to public and private sector companies in emerging countries: A study of Indian purchasing managers. Journal of International Marketing 1999; 7(3): 64-83.

[83] Mummalaneni V, Dubas K M, Chao C. Chinese purchasing managers' preferences and trade-offs in supplier selection and performance evaluation. Industrial Marketing Management 1996; 25(2): 115-124.

[84] Park D, Krishnan HA. Understanding supplier selection practices: Differences between U.S. and Korean executives. Thunderbird International Business Review 2001; 43(2): 243255.

[85] Rao CP, Seshadri S. Industrial buyers' expectations of supplier attributes across developing countries: Implications for marketing strategies. The International Executive 1996; 38(5): 671-689.

[86] Swift CO, Gruben KH. Gender differences in weighting of supplier selection criteria. Journal of Managerial Issues 2000; 12(4): 502-512.

[87] An Evaluation of Industrial Purchasing and Distribution Trends: A Research Investigation, Cleveland, American Machinery Manufacturers Association, 1985. 
[88] Lehmann DR, O'Shaugnessy J. Decision criteria used in buying different categories of products. Journal of Purchasing and Materials Management 1982; 18(1): 9-14.

[89] Evans RH. Product involvement and industrial buying. Journal of Purchasing and Materials Management 1982; 18(2): 23-28.

[90] Kiser GE, Rao CP, Rao SRG. Vendor attribute evaluations of buying center members others than purchasing executives. Industrial Marketing Management 1975; 4: 178-184.

[91] Lehmann DR, O'Shaughnessy J. Differences in attribute importance for different industrial products. Journal of Marketing 1974; 38: 36-42.

[92] White PD. Decision making in the purchasing process: A report. New York: AMACOM, 1978.

[93] Shipley D, Egan C, Edgett S. Meeting source selection criteria: Direct versus distributor channels. Industrial Marketing Management 1991; 20(4): 297-303.

[94] Shipley D, Prinja S. The services and supplier choice influences of industrial distributors. Service Industries 1988; 8: 176-187.

[95] Vonderembse MA, Tracey M, Tan CL, Bardi EJ. Current purchasing practices and JIT: Some of the effects of inbound logistics. International Journal of Physical Distribution and Logistics 1995; 25(3): 33-48.

[96] Choi TY, Hartley JL. An exploration of supplier selection practices across the supply chain. Journal of Operations Management 1996; 14(4): 333-343.

[97] Cardozo RN, Cagley JW. Experimental study of industrial buyer behavior. Journal of Marketing Research 1971; 8: 329-334.

[98] Tullous R, Munson JM. Tradeoffs under uncertainty: Implications for industrial purchasers. International Journal of Purchasing and Materials Management 1991; 27(3): 24-31.

[99] Hakansson Hakan, Wootz B. Supplier selection in an international environment - An experimental study. Journal of Marketing Research 1975; 75 (12): 46-51.

[100] Goffin K, Szwejczewski M, New C. Managing suppliers: When fewer can mean more. International Journal of Physical Distribution \& Logistics Management 1997; 27(7): 422436.

[101] Ittner CD, Larcker DF, Nagar V, Rajan MV. Supplier selection, monitoring practices, and firm performance. Journal of Accounting and Public Policy 1999; 18: 253-281.

[102] Kannan VR, Tan KC. Attitudes of US and European managers to supplier selection and assessment and implications for business performance. Benchmarking 2003; 10(5): 472489.

[103] Tracey M, Tan CL. Empirical analysis of supplier selection and involvement, customer satisfaction, and performance. Supply Chain Management 2001; 6(4): 174-188. 
Table 1: Prior Studies of Selection Criteria

\begin{tabular}{lll}
\hline Primary Focus & \multicolumn{1}{c}{ Topic Area } & \multicolumn{1}{c}{ Studies } \\
\hline & Environmental Considerations & {$[68]$} \\
\cline { 2 - 3 } & Import Purchases & {$[69][70][71][72][73]$} \\
\cline { 2 - 3 } Impact of Cycle Time & {$[74]$} \\
\cline { 2 - 3 } Environment & Industry Focus & {$[75][76][77][78][79][80]$} \\
\cline { 2 - 3 } & International Purchasing Practices & {$[81][82][83][84][85]$} \\
\cline { 2 - 3 } & Male versus Female Buyers & {$[86]$} \\
\cline { 2 - 3 } & Materials/Capital Equipment & {$[87]$} \\
\cline { 2 - 3 } & Product Attribute & {$[88]$} \\
\cline { 2 - 3 } & Routine/Non Routine Purchases & {$[6][89][90][91][92]$} \\
\cline { 2 - 3 } & Buyer/Supplier Partnerships & {$[1][42]$} \\
\cline { 2 - 3 } Strategic Issues & Criteria Importance versus Use & {$[5]$} \\
\cline { 2 - 3 } & Distributor versus Producer & {$[93][94]$} \\
\cline { 2 - 3 } & Just in Time Purchasing & {$[95]$} \\
\cline { 2 - 3 } & Location of Buyer in Supply Chain & {$[96]$} \\
\cline { 2 - 3 } & Purchase Risk & {$[97][98][99]$} \\
\cline { 2 - 3 } & Single/Multiple Sources & {$[2]$} \\
\cline { 2 - 3 } & Supply Base Reduction & {$[100]$} \\
\hline Performance & Firm Performance & {$[1][101][102][103]$} \\
\cline { 2 - 3 } Issues & Manufacturing Performance & {$[11]$} \\
\hline * Routine purchases & are recurring purchases where there are no anticipated problems \\
regarding how the & materials/products will be used or whether they will meet buyer needs.
\end{tabular}

Table 2: Literature Support for Proposed Constructs

\begin{tabular}{|c|c|c|}
\hline Construct & Indicator & Sample Literature Support \\
\hline \multirow{7}{*}{$\begin{array}{l}\text { Supplier } \\
\text { Quality }\end{array}$} & Testing capability & {$[42][70][75][78][85][98]$} \\
\hline & Scope of resources & {$[1][1][85][102]$} \\
\hline & Technical expertise & {$[1][42][70][72][75][78][79][82]$} \\
\hline & Industry knowledge & {$[1][70][102]$} \\
\hline & Commitment to quality & {$[1][82][85][96][101][102][103]$} \\
\hline & Supplier's process capability & {$[1][42][70][75][78][82][84]$} \\
\hline & Commitment to continuous improvement & {$[1][78][96][101][102]$} \\
\hline \multirow{5}{*}{$\begin{array}{l}\text { Supplier } \\
\text { Service }\end{array}$} & Ability to meet delivery due dates & {$[69][70][71][72][73][75][78][82]$} \\
\hline & Price of materials, parts and services & {$[69][70][71][72][73][75][78][81]$} \\
\hline & Flexible contract terms and conditions & {$[69][70][71][72][73][85][91][94]$} \\
\hline & Geographical compatibility/proximity & {$[1][70][86][96][99][2][102]$} \\
\hline & Reserve capacity for unexpected demand & {$[71][73][79][82][85][91][96]$} \\
\hline \multirow{8}{*}{$\begin{array}{c}\text { Strategic/ } \\
\text { Management } \\
\text { Fit }\end{array}$} & Open to site evaluation & {$[1][101][102]$} \\
\hline & References/reputation of supplier & {$[1][70][71][73][78][81][82][84]$} \\
\hline & Financial stability and staying power & {$[1][70][78][82][84][86][96][2]$} \\
\hline & Honest and frequent communications & {$[71][73][82][85][94][96]$} \\
\hline & Cultural match between the companies & {$[1][1][84][102]$} \\
\hline & Past and current relationship with supplier & {$[69][75][78][82][83][85][86]$} \\
\hline & Supplier has strategic importance to your firm & {$[1][42][96][101][102]$} \\
\hline & Supplier's willingness to share confidential info & {$[1][42][96][102]$} \\
\hline
\end{tabular}


Table 3: Respondent Profile

\begin{tabular}{|c|c|c|c|}
\hline DEMOGRAPHIC INFORMATION & ISM-US & $\begin{array}{c}\text { APICS- } \\
\text { US }\end{array}$ & $\begin{array}{l}\text { APICS- } \\
\text { Europe }\end{array}$ \\
\hline SAMPLE SIZE (number) & 100 & 310 & 115 \\
\hline \multicolumn{4}{|l|}{ INDUSTRY TYPE $(\%)$} \\
\hline Miner/Raw Material Extractor & 0.0 & 0.0 & 0.0 \\
\hline Raw Material Manufacturer & 6.1 & 2.9 & 3.4 \\
\hline Component Manufacturer & 25.3 & 10.5 & 15.5 \\
\hline Final Product Manufacturer & 61.6 & 38.2 & 42.2 \\
\hline Wholesaler & 1.0 & 13.1 & 2.6 \\
\hline Retailer & 0.0 & 5.2 & 0.9 \\
\hline Services (other than Wholesale/Retailer) & 4.0 & 28.1 & 33.6 \\
\hline Others & 2.0 & 2.0 & 1.7 \\
\hline \multicolumn{4}{|l|}{ FIRM SIZE - NUMBER OF EMPLOYEES $(\%)$} \\
\hline Less Than 50 & 7.9 & 8.3 & 7.5 \\
\hline $51-200$ & 19.1 & 21.4 & 12.3 \\
\hline $201-500$ & 30.3 & 19.0 & 19.8 \\
\hline $501-1,000$ & 15.7 & 8.7 & 13.2 \\
\hline 1,001 and above & 27.0 & 42.6 & 47.2 \\
\hline \multicolumn{4}{|l|}{$\underline{\text { ANNUAL GROSS SALES IN US\$ }(\%)}$} \\
\hline Less Than $\$ 1,000,000$ & 0.0 & 3.1 & 12.7 \\
\hline$\$ 1,000,001-\$ 5,000,000$ & 5.2 & 5.0 & 5.0 \\
\hline$\$ 5,000,001-\$ 10,000,000$ & 2.6 & 4.3 & 5.0 \\
\hline$\$ 10,000,001-\$ 50,000,000$ & 33.8 & 21.3 & 14.0 \\
\hline $50,000,001$ and above & 58.4 & 66.3 & 63.3 \\
\hline
\end{tabular}


Table 4: Descriptive Statistics $(\bar{x}=$ mean, $\sigma=$ standard deviation $)$

\begin{tabular}{|c|c|c|c|c|c|c|}
\hline \multirow{2}{*}{$\begin{array}{l}\text { Supplier Selection Construct/Measured Variables } \\
\text { Supplier Quality }\end{array}$} & \multicolumn{2}{|c|}{$\begin{array}{l}\text { ISM-US } \\
(\mathrm{N}=100)\end{array}$} & \multicolumn{2}{|c|}{$\begin{array}{l}\text { APICS-US } \\
(\mathrm{N}=310)\end{array}$} & \multicolumn{2}{|c|}{$\begin{array}{l}\text { APICS-Europe } \\
\qquad(\mathrm{N}=115)\end{array}$} \\
\hline & $\bar{x}$ & $\sigma$ & $\bar{x}$ & $\sigma$ & $\bar{x}$ & $\sigma$ \\
\hline 1. Testing capability & 4.06 & 0.89 & 3.68 & 1.00 & 3.57 & 0.97 \\
\hline 2. Scope of resources & 3.78 & 0.82 & 3.66 & 0.88 & 3.42 & 0.87 \\
\hline 3. Technical expertise & 4.46 & 0.63 & $* *$ & $* *$ & $* *$ & $* *$ \\
\hline 4. Industry knowledge & 4.24 & 0.79 & 4.01 & 0.92 & 4.10 & 0.77 \\
\hline 5. Commitment to quality & 4.65 & 0.61 & 4.58 & 0.78 & 4.48 & 0.84 \\
\hline 6. Supplier's process capability & 4.23 & 0.81 & 3.91 & 1.00 & 3.80 & 1.02 \\
\hline 7. Commitment to continuous improvement & 4.33 & 0.79 & 3.87 & 1.07 & 3.82 & 1.08 \\
\hline$\underline{\text { Supplier Service }}$ & $\bar{x}$ & $\sigma$ & $\bar{x}$ & $\sigma$ & $\bar{x}$ & $\sigma$ \\
\hline 1. Ability to meet delivery due dates & 4.76 & 0.47 & 4.57 & 0.75 & 4.43 & 0.67 \\
\hline 2. Price of materials, parts and services & 4.37 & 0.75 & 4.09 & 0.88 & 4.02 & 0.98 \\
\hline 3. Flexible contract terms and conditions & 4.03 & 0.85 & 3.71 & 0.96 & 3.68 & 0.79 \\
\hline 4. Geographical compatibility/proximity & 3.29 & 1.04 & 3.00 & 1.15 & 2.97 & 1.06 \\
\hline 5. Reserve capacity to respond to unexpected demand & 4.27 & 0.77 & 4.02 & 1.00 & 3.96 & 0.93 \\
\hline$\underline{\text { Strategic/Managerial Fit }}$ & $\bar{x}$ & $\sigma$ & $\bar{x}$ & $\sigma$ & $\bar{x}$ & $\sigma$ \\
\hline 1. Open to site evaluation & 4.10 & 0.88 & $*$ & $*$ & $*$ & $*$ \\
\hline 2. References/reputation of supplier & 3.91 & 0.79 & 3.84 & 0.92 & 3.65 & 0.97 \\
\hline 3. Financial stability and staying power & 4.31 & 0.70 & 3.93 & 0.90 & 3.66 & 0.97 \\
\hline 4. Honest and frequent communications & 4.24 & 0.77 & 4.06 & 0.91 & 3.91 & 0.90 \\
\hline 5. Cultural match between the companies & 3.03 & 1.12 & 2.86 & 1.15 & 2.80 & 1.12 \\
\hline 6. Past and current relationship with supplier & 3.82 & 0.84 & 3.57 & 0.92 & 3.46 & 0.93 \\
\hline 7. Supplier has strategic importance to your firm & 3.94 & 0.92 & 3.70 & 1.02 & 3.71 & 0.97 \\
\hline 8. Supplier's willingness to share confidential info & 3.67 & 0.99 & 3.28 & 1.00 & 3.28 & 1.04 \\
\hline $\begin{array}{l}\text { Item was removed during exploratory analys } \\
\text { (less than 0.5) }\end{array}$ & f the & & datc & to & fact & ding \\
\hline $\begin{array}{l}\text { ** Item was removed during exploratory analys } \\
\text { variance in the measurement model. }\end{array}$ & the & & datc & to & er & \\
\hline
\end{tabular}


Table 5: Exploratory Analyses of the ISM Sample

\begin{tabular}{|c|c|c|c|}
\hline Supplier Selection Construct/Observed Variable & $\begin{array}{l}\text { Factor } \\
\text { Loading }\end{array}$ & Std $\alpha$ & $\begin{array}{c}\% \text { of } \\
\text { Variation }\end{array}$ \\
\hline \multicolumn{4}{|l|}{ Supplier Quality } \\
\hline 1. Testing capability & .686 & \multirow{7}{*}{.7904} & \multirow{7}{*}{$44.7 \%$} \\
\hline 2. Scope of resources & .722 & & \\
\hline 3. Technical expertise & .791 & & \\
\hline 4. Industry knowledge & .646 & & \\
\hline 5. Commitment to quality & .617 & & \\
\hline 6. Supplier's process capability & .612 & & \\
\hline 7. Commitment to continuous improvement & .581 & & \\
\hline \multicolumn{4}{|l|}{ Supplier Service } \\
\hline 1. Ability to meet delivery due dates & .651 & \multirow{5}{*}{.6177} & \multirow{5}{*}{$39.6 \%$} \\
\hline 2. Price of materials, parts and services & .594 & & \\
\hline 3. Flexible contract terms and conditions & .684 & & \\
\hline 4. Geographical compatibility/proximity & .590 & & \\
\hline 5. Reserve capacity to respond to unexpected demand & .624 & & \\
\hline \multicolumn{4}{|l|}{ Strategic/Managerial Fit } \\
\hline 1. Open to site evaluation & .449 & \multirow{8}{*}{.7794} & \multirow{8}{*}{$39.8 \%$} \\
\hline 2. References/reputation of supplier & .603 & & \\
\hline 3. Financial stability and staying power & .646 & & \\
\hline 4. Honest and frequent communications & .649 & & \\
\hline 5. Cultural match between the companies & .577 & & \\
\hline 6. Past and current relationship with supplier & .688 & & \\
\hline 7. Supplier has strategic importance to your firm & .695 & & \\
\hline 8. Supplier's willingness to share confidential info & .698 & & \\
\hline
\end{tabular}

Std $\alpha=$ standardized $\alpha$

$\%$ of variation $=$ percent of variation in the data explained by the factor 


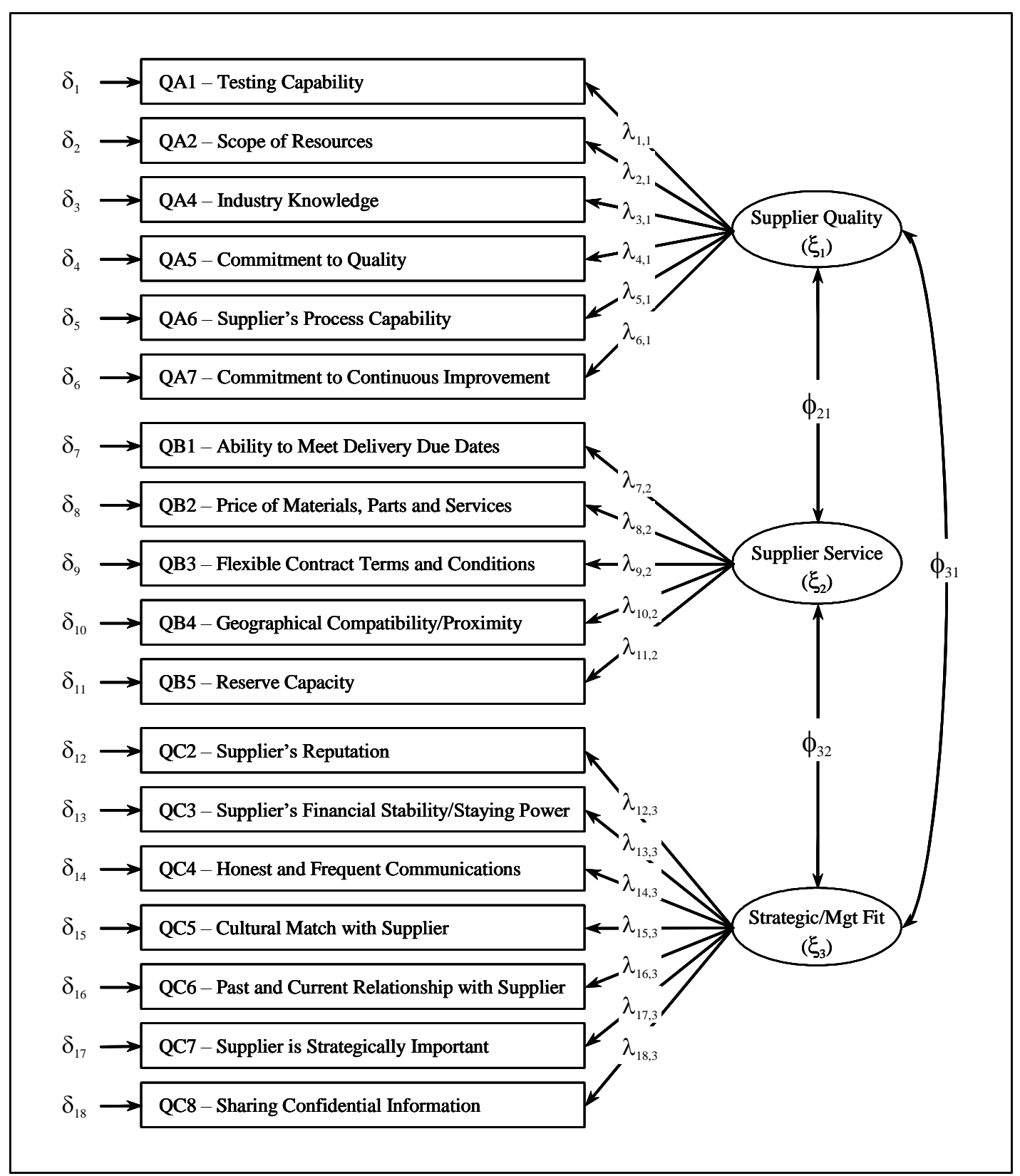

Figure 1: Conceptual Three-Factor Supplier Selection Construct 


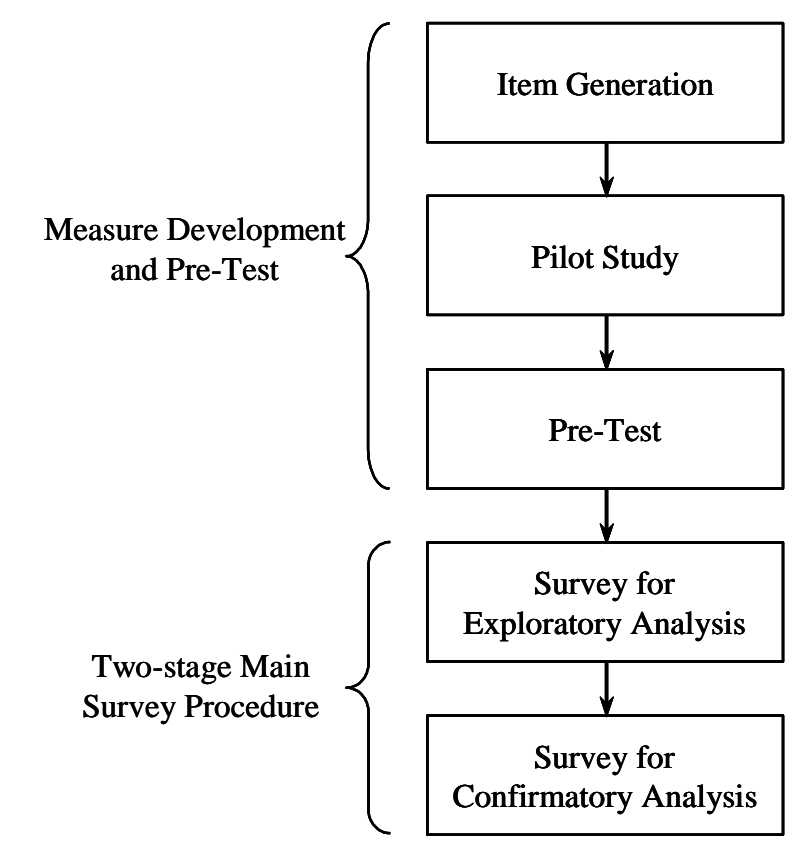

Based on past literature and focused group discussions with practitioners

Ten senior purchasing and materials managers assessed the initially developed items

The revised survey instrument was mailed to another 20 senior purchasing and supply managers for refinement

Surveys mailed to 1,500 U.S. members of the Institute for Supply Management (ISM-US)

Surveys mailed to 2,982 U.S. members (APICS-US) and 970 European members (APICS-Europe) of the Educational Society for Resource Management (APICS)

Figure 2: Procedures Used to Develop and test the Research Construct 


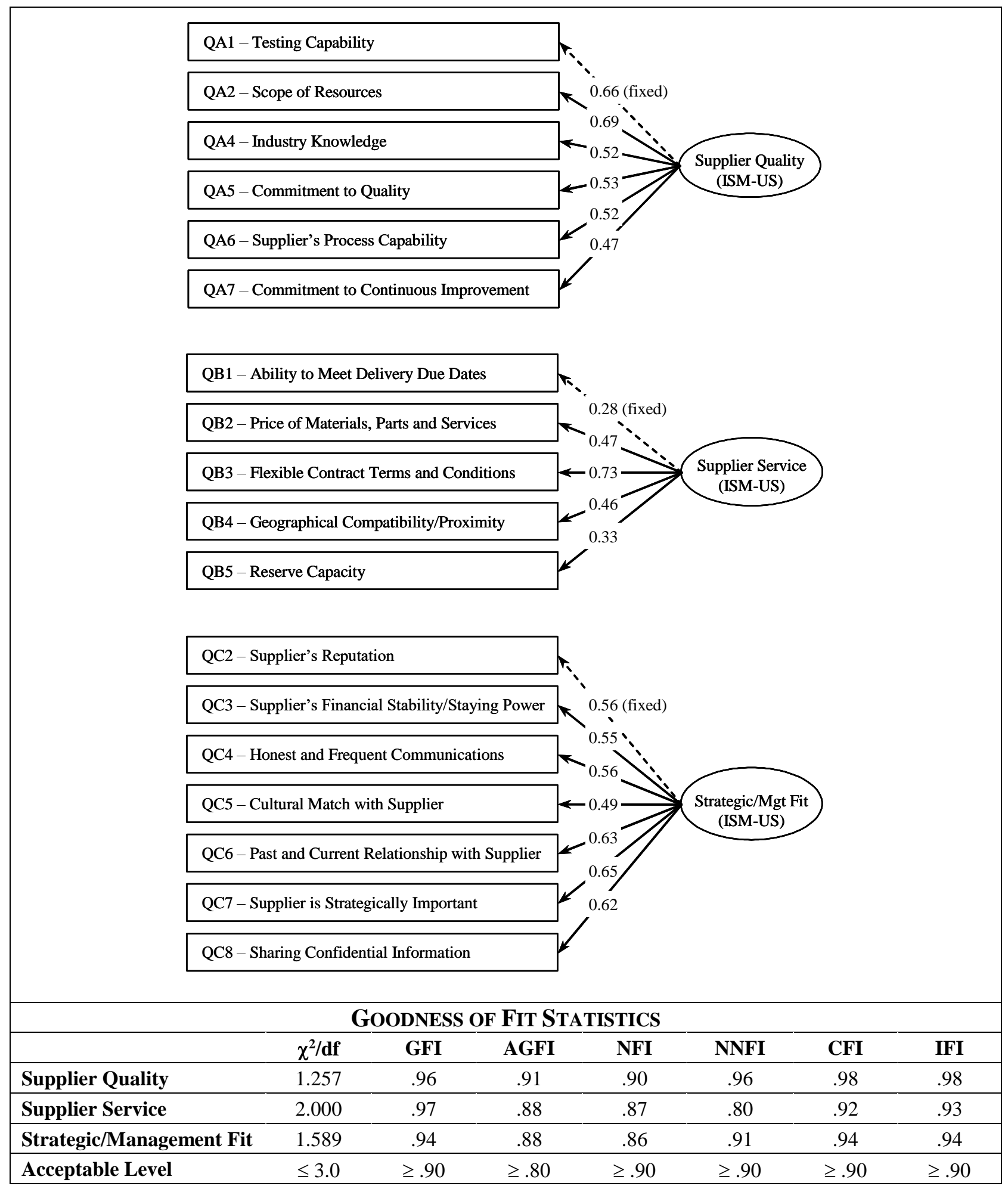

Figure 3: Exploratory Measurement Models (ISM-US) 


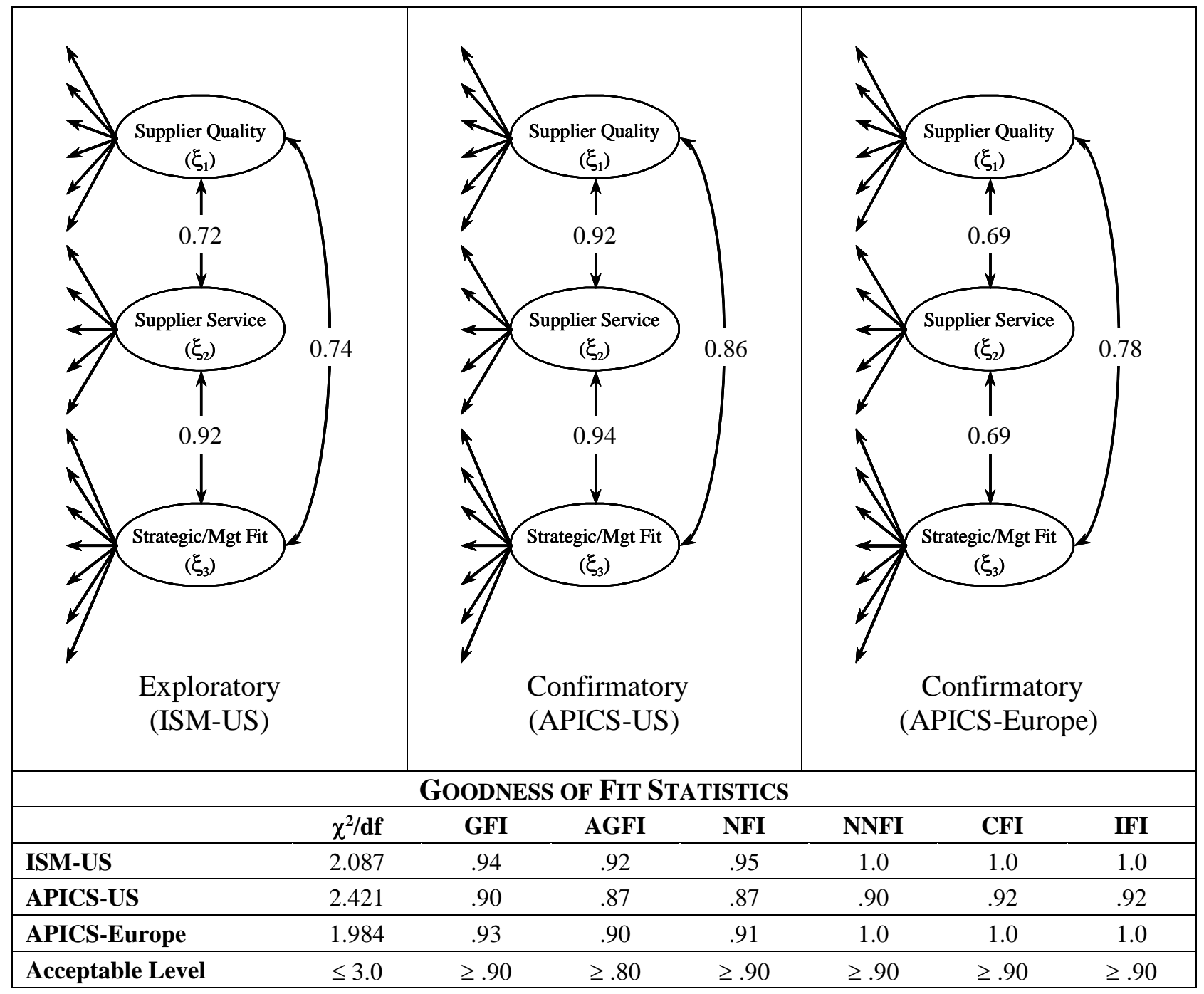

Figure 4: Three-Factor Supplier Selection Constructs 


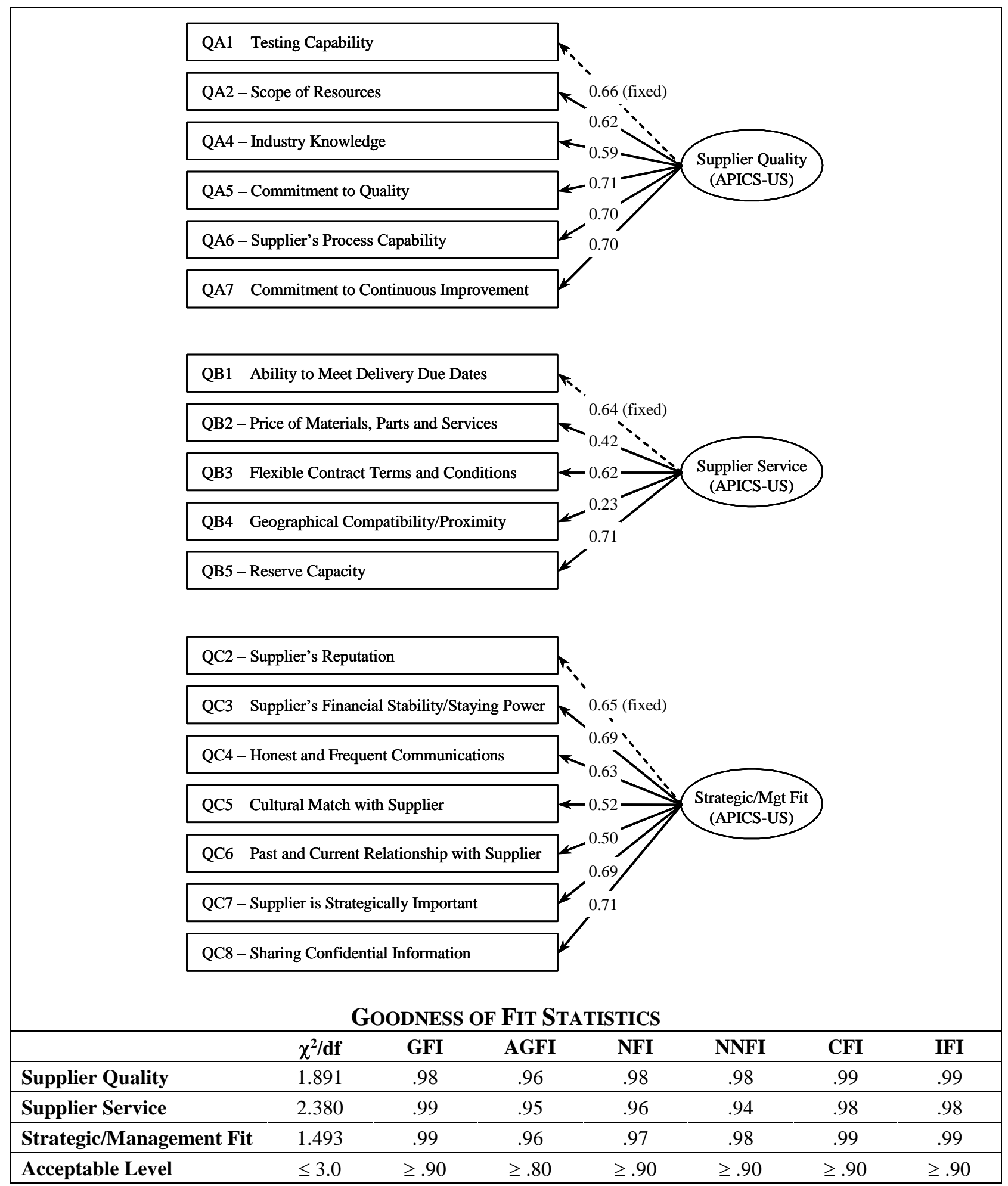

Figure 5: Validation Measurement Models (APICS-US) 


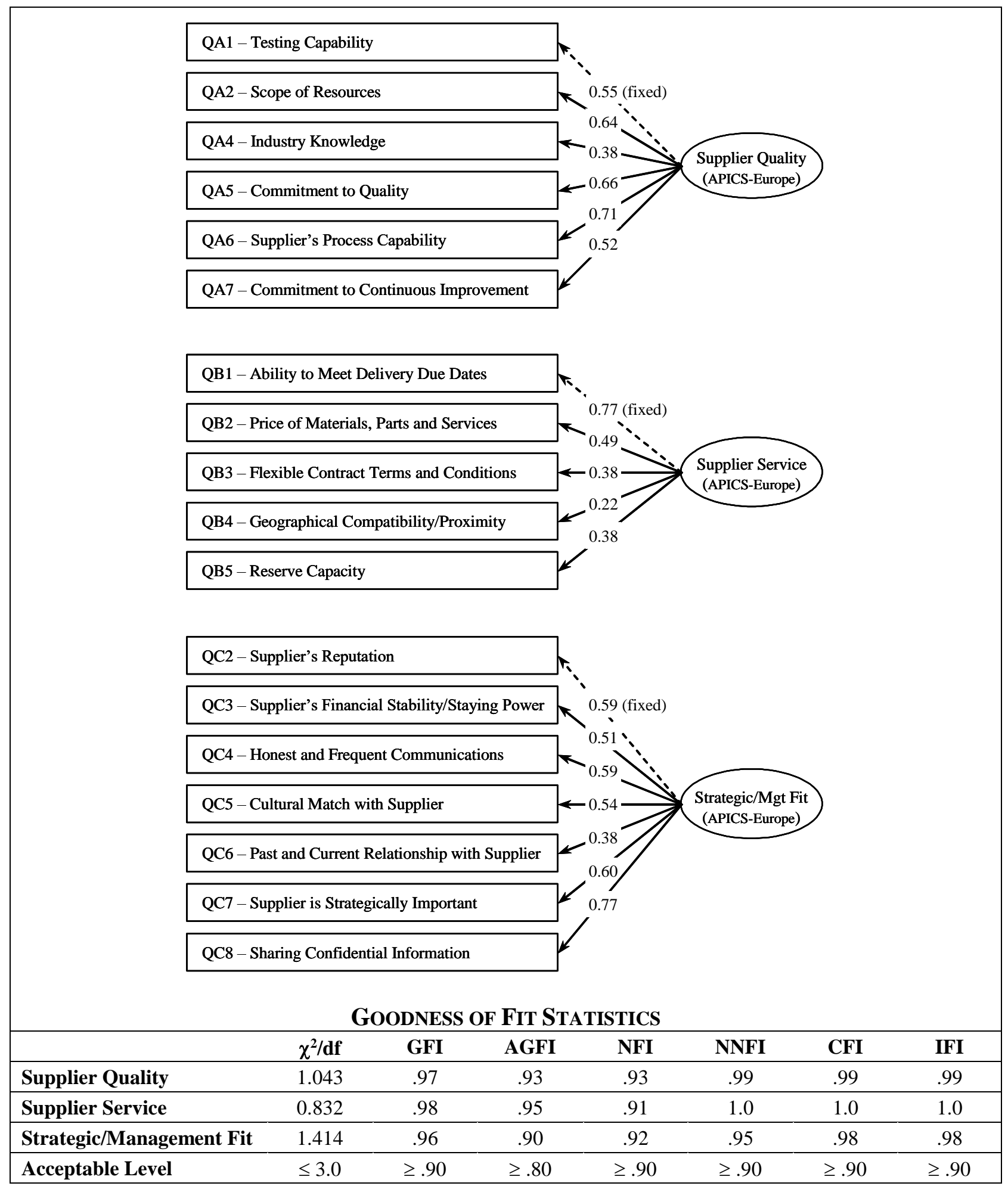

Figure 6: Validation Measurement Models (APICS-Europe) 


\section{APPENDIX - Survey Instrument}

Please circle the most appropriate response on a scale of 5 (high) to 1 (low).

How important are the following factors (with respect to your supplier) when selecting a key/preferred supplier for your organization?

\section{(1) Supplier Quality Issues}
(A) Testing capability
(B) Scope of resources
(C) Technical expertise
(D) Industry knowledge
(E) Commitment to quality
(F) Supplier's process capability
(G) Commitment to continuous improvement in product and process

\section{(2) Supplier Service Issues}
(A) Ability to meet delivery due dates
(B) Price of materials, parts and services
(C) Flexible contract terms and conditions
(D) Geographical compatibility/proximity
(E) Reserve capacity or the ability to respond to unexpected demand

\section{(3) Strategic/Management Fit Issues}
(A) Open to site evaluation
(B) References/reputation of supplier
(C) Financial stability and staying power
(D) Honest and frequent communications
(E) Cultural match between the companies
(F) Past and current relationship with supplier
(G) Supplier has strategic importance to your firm
(H) Supplier's willingness to share confidential information 